\title{
9
}

\section{Reducing the Boundaries Between the Community and the Academy With a Full-Time Service Learning Capstone}

\author{
Andy Ballard \\ Auckland University of Technology, NZ
}

The purpose of this paper is to share my experiences as the instructor of a full-time, single semester, servicelearning capstone course. In this innovative course students already volunteering in the Students in Free Enterprise (SIFE) organization work in teams to identify community needs and address them using their business skills and knowledge and an entrepreneurial approach. The student teams are responsible for all phases of the work, from working with the community to identify needs through planning solutions to implementation and measurement. The students' work is assessed through presentation, report, reflection and peer evaluation.

\section{Introduction}

In this paper I will present an innovative model for service learning where students at Auckland University of Technology (AUT) in New Zealand use their work in the Students in Free Enterprise (SIFE) ${ }^{1}$ organization as a vehicle for applied learning in the community.

In the SIFE organization students work to apply business knowledge and an entrepreneurial mindset to improve the quality of life and standard of living of people in need in their communities (SIFE, 2012a). The Auckland University of Technology branch of the Students in Free Enterprise organization (SIFE AUT) has been highly successful over the 10 years of its existence, winning the SIFE New Zealand National Championships five times and placing runner up in each of the other years. SIFE AUT typically runs between five and 10 concurrent projects to benefit the community, with some of these lasting several years.

Worldwide, SIFE is present on around 1,600 universitycampuses(SIFE, 2012a).Aspertheorganization's guidelines, SIFE teams are only allowed to exist if they can show that they are financially sustainable and have the support of their institution, so it can reasonably be assumed that each of these 1,600 teams is active. What makes our University's approach to SIFE unusual is that

\footnotetext{
${ }^{1}$ Shortly after this paper was submitted, the Students in Free Enterprise (SIFE) was rebranded worldwide as Enactus; however, the programme itself remains the same. The references are unchanged.
} 
this multidisciplinary applied learning is formally assessed in a full semester capstone course. In other words, we do not view SIFE as an additional activity, unrelated to the students' classroom learning, nor do we view it as a simple source of credit for community volunteering. Rather, we view SIFE as an integral part of our students' learning - a service learning experience that is based on principles of problem-based learning, a capstone experience structured around the principles of engagement theory.

\section{Background}

Over 50 years ago, John Dewey (1956) claimed that effective learning requires the right context, which can be gained through a combination of environment and experience. Service learning provides exactly that when correctly implemented. Service learning is "an academically rigorous and integrated real-world course project where students produce tangible, professional products for use in the local community as they work with and learn from organizations designed to serve community needs," but with the addition of "or directly with the communities themselves" (Kenworthy-U'Ren, 1999, p. 382). Service learning is hence more than volunteerism. Rather, it is a structured activity where the projects undertaken are founded on appropriate theory, have clear objectives and where there is a reflective component (Hatcher \& Bringle, 1997; Kenworthy-U'Ren \& Peterson, 2005).

There have been many criticisms of servicelearning, some of which view it as a form of political indoctrination in which the liberal views of the academy are foisted on an unsuspecting student body by preaching the evils of capitalism and the moral superiority of the poor - a form of re-education in which students are taught the 'right' way to think (Bankston, 2011; Butin, 2010). The model I am using as an instructor here at AUT is in stark contrast to this. The SIFE organization already has a global mission to "improve the quality of life and standard of living of people in need in the community... [while] creating meaningful opportunities for learning and exchange among the participants" (SIFE, 2012a, para. 2). It aims to "create a more sustainable world through the positive power of business" while developing socially responsible business leaders (SIFE, 2012a, para. 1). Yes, this is still political, but at least the politics are clear. The overt and covert messages are one and the same: business is not inherently bad and by adopting a triple bottom line approach business can be used to create social good. While I certainly agree with Godfrey (1999) that business can and should be used to further social justice, I disagree with him that affecting students' moral development is a principal aim of service learning. I am interested in ensuring students are aware of the social possibilities of business, but I do not believe I should directly try to influence their morals.

In the SIFE course at AUT I am not dictating to my students what community needs they should address, so my own values are certainly not being forced on the students. It is entirely up to the students to work with the community to define and identify the needs in that community. My role as the academic is to ensure that the projects they choose to run are sufficiently grounded in academic theory as to be worth pursuing. In other words the work is student-directed, not lecturer directed, which addresses one of Butin's (2010) key criticisms of many service learning initiatives.

Another criticism of service learning is that it is doubtful whether the supposed beneficiaries of the project actually receive any long-lasting benefits (Cruz $\&$ Giles, 2000). At AUT we are certain that they do benefit. All SIFE AUT projects have to design and embed measurement into the project so that they are able to demonstrate any increases in standard of living or quality of life for the targeted people in need. If the planned increases cannot be demonstrated then the project is revised. The academic legitimacy gained by embedding this course in the SIFE AUT organization increases the assistance available to students engaging in service learning through the provision of additional academic support. It further allows for the creation of long-term projects that are not dependent on the whims of a particular student cohort. For example, some of the projects at SIFE AUT have worked with the same target group for six years.

Our approach also challenges the assumptions of students doing work for the community. In the SIFE course, students are working with the community, alongside the people in need from design to implementation, ensuring long term empowerment through knowledge transfer. Empowerment is a key feature of all SIFE projects, as can be seen in the Projects section below.

Another facet of this course is that the students work together in interdisciplinary teams, so that students majoring in areas such as marketing, finance, economics, human resource management, and product design work 
together in project teams. This inter-disciplinary approach to integration ensures knowledge sharing between the students helps to increase the range of projects undertaken, and also mirrors the real-world interactions of workers in a range of functional areas (Harden, 2000).

The course is also designed according to the problem-first principles of problem-based learning, where the initial community need identified by the students in conjunction with the community becomes the driver for their learning through the semester (Spencer \& Jordan, 1999). Further, since the SIFE AUT projects are collaborative, project-based and authentic (real), they also fit with the definition of engagement theory which is described as requiring active students working on group projects with an external focus (Kearsley \& Shneiderman, 1998).

\section{Structure}

In any given semester, students who have been active members of SIFE AUT for at least one semester and who have a $\mathrm{B}$ grade average (where passing grades are $\mathrm{A}$ to $\mathrm{C}$ ) are able to opt to complete their compulsory cooperative education capstone course within the SIFE AUT organization. To be members of SIFE AUT, the students would have passed a structured selection interview with two members of the SIFE AUT Executive Team in which their problem-solving, empathy, and motivation to join are explored.

Once accepted into the academic course, the students begin by researching needs in the community that they are interested in and feel competent they can address. To support them in this, the SIFE AUT organization maintains a list of needs previously identified but not yet addressed.

After one week of research the students present their initial project ideas to the SIFEAUT Student Executive and me. Those that are organizationally and academically viable are then pitched to the full SIFE AUT organization. Organizational viability is determined by the Executive and is based on resource availability, alignment with the SIFE International Criterion, and the SIFE AUT strategic plan. Academic viability is judged by me based on the relevance of the project to the academic backgrounds of the students. The students then rank their three preferred projects and are assigned to teams by me and the SIFE AUT Student President based on project resource requirements and student skills and preferences. Similar to Fairfield (2010),
I have observed that the students are far more motivated to work on their project teams when I use this selection approach than when I previously used to simply assign them to project teams without discussion. The students spend the rest of their fifteen-week semester working in their project teams. During this time they work closely with the relevant people in need to refine the definition of the need, design a suitable project to address the need, implement the project and then measure its success.

There is no new formal content to be covered in the course. Instead, given that this is a capstone, the students are expected to make use of their learning from throughout their degree, supplementing it with additional research as necessary. This capstone functions as both 'magnet' (pulling discipline content together) and 'mountaintop' (integrating diverse discipline approaches), by consolidating degree learning and by being interdisciplinary (van Acker \& Bailey, 2011).

Around half of all SIFE AUT projects are planned in multiple phases where they continue into subsequent semesters. In this case, the particular students working on the project may be entirely different in each phase. Each project is carefully documented by its student team as part of their academic requirements, so they do not depend on me as the instructor for their continuation. In addition, even if SIFE ceased to exist, the University is committed to continuing this course using an equivalent vehicle to SIFE, which we would establish on campus.

\section{Assessment}

The students are not assessed academically on the successful outcomes of their projects, although the SIFE organization itself does encourage this form of success through its SIFE World Cup annual competition (SIFE, 2012b). Instead, the students' academic performance is measured through a team presentation, a team report and an individual reflection, all based on the process that they have followed.

The SIFE National and World Cup competitions give considerable accountability to the work of SIFE teams. They involve public reporting of projects and project outcomes, judged by a panel of senior businesspeople, social entrepreneurs and community leaders, and audits for the work of the first and second place teams in each competition. The views of the people whom the SIFE teams claim to have empowered are particularly important. 
In the presentation, which takes place in week five of the semester, the teams present their project plan including timeline, budget and task allocation, and an explanation of how the project fits the SIFE international criterion. All team members receive the same mark, but this is modified by the peer evaluation that all team members complete (Appendix).

The team report is submitted at the end of the semester. It presents, analyzes and reviews the implementation of the project. Students are required to demonstrate how they have applied discipline knowledge during their project. This report is also subject to peer evaluation of team member contribution using the same evaluation form.

The final reflective assessment requires the students to demonstrate the insights they have developed into their contribution to their project team and/or the contribution of their academic discipline to solving real problems in their project. It is designed to encourage students to develop a habit of reflecting on and taking responsibility for their own learning and personal growth.

\section{Projects}

The projects that the students undertake vary enormously. In the Lifeskills project SIFE AUT students worked with educators, parents and schoolchildren to identify gaps in the school curricula. They then designed and ran a series of experiential workshops to help 13 and 14 year olds to develop skills in financial literacy, goal setting, environmental sustainability and entrepreneurship. They did this by teaching their project participants how to create and sell products made from waste material, with a theme of turning trash into cash. The schoolchildren self-reported increases in their ability to set and achieve goals, demonstrated increased financial literacy and claimed increased understanding of how to make a concrete difference in environmental issues. One team of four made a profit of over NZ $\$ 200$ with just three hours of work. A teacher commented: "My students took a lot of pride in what they were doing and enjoyed the practical aspect of putting learning into a physical reality." This project is ongoing, with extensive documentation allowing the project to be continued by a new SIFE AUT team each semester.

In the Lifewise project SIFE AUT students were determined to find a way to reduce homelessness. Lacking the skills to directly impact the homeless, they approached an existing community organization that works to empower homeless people with skills, knowledge and job opportunities. The SIFE AUT students helped them to improve their business model so that this organization could increase their capacity to assist homeless people by over $50 \%$, leading to a reduction in the rate of rough sleeping.

\section{Student Outcomes}

The typical themes that emerge in student evaluations of this course are the enjoyment of applying knowledge to address community problems, the practical nature of the class and the amount of independent yet supported learning. The main criticism of the course is the high workload, which sometimes comes as a shock to students who are used to having a large amount of discretionary time. Working 3540 hours per week on their SIFE AUT project for 15 weeks and also doing their academic work for the SIFE paper is certainly not easy, but it probably is a good starting point as the students begin their transition to graduate life.

\section{The Future}

Although any student undertaking any qualification can join SIFE AUT, currently only students studying the Bachelor of Business are eligible to take the SIFE course for academic credit. I am presently in the process of expanding this option to other faculties, broadening the skills in the project teams and allowing a wider range of projects to be undertaken. The first school to participate in this way (the School of Physiotherapy) is currently working with me to develop its own course so that their students can work alongside my business students in a new academic course in SIFE AUT.

Finally, there is clear need for research to determine whether all parties (the community, the academy, the students) feel more connected to one another as a result of this course.

\section{Author's Note}

I would like to thank the three anonymous reviewers for their thoughts and comments, and Keith Macky for encouraging me to write this in the first place and for his considerable wisdom when addressing revisions. 


\section{References}

Bankston, C.L. (2011). Modern orthodoxies. Retrieved from http://www.popecenter.org/commentaries/ article.html?id=2537

Butin, D.W. (2010). Service-learning in theory and practice - The future of community engagement in higher education. New York: Palgrave Macmillan.

Cruz, N.I. \& Giles, D.E., Jr. (2000). Where's the community in service-learning research? Michigan Journal of Community Service Learning (Special Issue), 28-34.

Dewey, J. (1956). Experience in education. New York: Macmillan.

Fairfield, K.D. (2010). Growing up and growing out. Emerging adults learn management through service-learning. Journal of Management Education, 34(1), 113-141.

Godfrey, P.C. (1999). Service-learning and management education. Journal of Management Inquiry, 8(4), 363-378.

Harden, R.M. (2000). The integration ladder: A tool for curriculum planning and evaluation. Medical Education, 34(7), 551-557.

Hatcher, J.A., \& Bringle, R.G. (1997). Bridging the gap between service and learning. College Teaching, 45(4).

Kearsley, G. \& Shneiderman, B. (1998). Engagement theory: A framework for technology-based teaching and learning. Retrieved from http://home. sprynet.com/ -gkearsley/engage.html

Kenworthy-U'Ren, A. L. (1999). Management students as consultants: An alternative perspective on the service-learning "call to action." Journal of Management Inquiry, 8(4), 379-387.

Kenworthy-U'Ren, A.L. \& Peterson, T.O. (2005). Service-learning and management education:
Introducing the "WE CARE" approach. Academy of Management Learning \& Education 4(3), 272277.

SIFE. (2012a). Our network. Retrieved from http://www. sife.org/aboutsife/Pages/Overview.aspx

SIFE. (2012b). Regional \& national competitions. Retrieved from http://www.sife.org/Programs andCompetitions/Pages/regionalnational competitions.aspx

Spencer, J.A. \& Jordan, R.K. (1999). Learner centred approaches in medical education. $B M J$, 318(7193), 1280-1283.

van Acker, L. \& Bailey, J. (2011). Embedding graduate skills in capstone courses. Asian Social Science, 7(4), 69-76. 


\section{Appendix}

\section{Peer Evaluation Form}

\section{Project Name:}

Student Name:

Student ID:

\begin{tabular}{|c|c|c|c|c|c|c|c|c|}
\hline & Peer 1 & Peer 2 & Peer 3 & Peer 4 & Peer 5 & Peer 6 & Peer 7 & Total \\
\hline \multicolumn{9}{|l|}{ Enter names of peers: } \\
\hline \multicolumn{9}{|l|}{$\begin{array}{l}\text { Attendance: } \\
\text { e.g. available for meetings, } \\
\text { came to class, came to } \\
\text { meetings, arrived on time, did } \\
\text { not leave early }\end{array}$} \\
\hline \multicolumn{9}{|l|}{$\begin{array}{l}\text { Communication: } \\
\text { e.g. exchanged contact details, } \\
\text { kept in contact, returned calls, } \\
\text { shared information, listened } \\
\text { actively, participated in team } \\
\text { discussion }\end{array}$} \\
\hline \multicolumn{9}{|l|}{$\begin{array}{l}\text { Collaboration: } \\
\text { e.g. participated in team } \\
\text { formation processes, } \\
\text { brainstormed effectively, } \\
\text { worked towards common } \\
\text { goals, consulted with others }\end{array}$} \\
\hline \multicolumn{9}{|l|}{$\begin{array}{l}\text { Contribution: } \\
\text { e.g. volunteered for tasks, } \\
\text { completed a fair share of the } \\
\text { work, applied knowledge to } \\
\text { problems, produced quality } \\
\text { work, met deadlines }\end{array}$} \\
\hline $\begin{array}{l}\text { Negotiation \& Conflict: } \\
\text { e.g. listened respectfully, } \\
\text { focussed on issues and } \\
\text { interests, used neutral } \\
\text { language, explored options for } \\
\text { agreement, identified } \\
\text { alternatives, checked for } \\
\text { assumptions, stereotypes } \\
\text { and/or perceptual differences, } \\
\text { evaluated options objectively }\end{array}$ & & & & & & & & \\
\hline Total & & & & & & & & \\
\hline
\end{tabular}

Notes on completing this form.

Assuming there are four people in your team (excluding you), you have $4 \times 10=40$ points to allocate between the four people on each of the criteria above. The 4 is the number of peers, and 10 is a fixed amount. So for the first line you might allocate 10,10,10,10 (total 40) if you thought the attendance was absolutely equal between the four of them. On the second line you might allocate $5,7,15,13$ (total 40) if you thought that Peer 3 outperformed the others in communication, and that Peer 1 was particularly weak in this area. After you have allocated points to all peers in each of the criteria, each criteria row total should add up to 40 and the grand total in the bottom right should be 200 .

How the scores you receive affect your final grade for the each of the team assessments.

If your team scored $10 / 15(66.7 \%, \mathrm{~B}-)$ for the presentation but you received a mean peer evaluation score of 57 , your personal final mark would be $10 / 15 \times 57 / 50=76 \%(B+)$ for the presentation. Alternatively, with a mean peer evaluation score of 35 , your mark would be $10 / 15 \times 35 / 50=46.7 \%$ (D) for the presentation. 